\title{
Revisiting forever gained: Income dynamics in the resettlement areas of Zimbabwe, 1983-1997
}

\author{
WPS/99-14

\section{Jan Willem Gunning, John Hoddinott, Bill Kinsey and Trudy Owens}

\author{
March 1999, This version: May 1999
}

\begin{abstract}
Address for correspodence: John Hoddinott
International Food Policy Research Institute

2033 K Street NW

Washington DC 20006

United States of America

email: J.Hoddinott-IFPRI@cgiar.org
\end{abstract}

Institutional affiliations: Gunning, University of Oxford and Free University, Amsterdam; Hoddinott, International Food Policy Research Institute; Kinsey, Free University, Amsterdam and University of Zimbabwe; Owens, University of Oxford.

\begin{abstract}
This paper examines income dynamics for a panel of households resettled on former white-owned farms in the aftermath of Zimbabwe's independence. There are four core findings: (i) there has been an impressive accumulation of assets by these households; (ii) while this accumulation has played a role in increases in crop income, increases in returns to these assets have been especially important in generating the dramatic increase in crop incomes observed in these households; (iii) differences in initial conditions across these households, such as previous farming experience, have few persistent effects; and (iv) growth in incomes has been shared across all households, with the largest percentage increases in predicted incomes recorded by households that had the lowest predicted incomes at the beginning of the survey.
\end{abstract}




\section{Introduction ${ }^{1}$}

Understanding the factors that cause incomes to change over time is important for understanding both the causes of poverty and for devising appropriate policies to address this poverty. In recent years, there has been an explosion of interest in this topic, with researchers literally running millions of regressions using cross-country data (Salai-i-Martin, 1997). Though interesting, such analyses often produce conflicting findings. A well known example is the debate over the impact of various policy, political and institutional factors on long-run average growth in per capita GDP. Levine and Renelt (1992, p. 943) claim that "the cross-country statistical relationships between long-run average growth rates and almost every particular policy indicator considered by the profession are fragile: small alterations in the 'other' explanatory variables overturn past results."

This paper examines the factors that account for income growth using longitudinal household level data. There are several attractions to such an approach. Conceptually, a core assumption underlying growth theory - that agents share common technologies - is considerably more plausible in a rural community than in the case of a cross-country study. The data used here have been collected, carefully checked, and cleaned by the authors. Consequently, these results are less subject to the whims and errors that bedevil national income accounts. Household level data more readily lend themselves to consideration of a wide number of econometric concerns such as endogeneity and the role of unobservables, issue that do not always receive appropriate consideration in the cross-country growth literature. It is also possible to examine changes in the distribution of incomes as well as changes in levels.

The data used in this study are drawn from a panel of households resettled on former whiteowned farms in the aftermath of Zimbabwe's independence. The paper examines the determinants of crop incomes in 1982/83 - the first year in which many of these households farmed this newly acquired land - and compares these results to those derived from data covering the 1995/96 agricultural year. There are four core findings: (i) there has been an impressive accumulation of assets by these households; (ii) while this accumulation has played a role in producing higher levels of crop income, increases in returns to these assets have been even more important in generating the dramatic increase in crop incomes observed in these households. This finding is robust to a wide variety of econometric concerns; (iii) differences in initial conditions across these households, such as previous farming experience, have few persistent effects. Although some of these variables affect output in the first year of observation, their impact is virtually non-existent by 1995/96; (iv) growth in incomes has been shared across all households, with the largest percentage increases in predicted incomes recorded by households that had the lowest predicted incomes at the beginning of the survey.

The paper begins with an introduction to the sample and its characteristics. Section 3 outlines the construction of the variables in the study and derives the finding that increases in returns to assets are the driving factor behind growth in household incomes. Section 4 demonstrates that these results are robust to econometric concerns regarding the construction of

\footnotetext{
${ }^{1}$ Funding for data collection under the Rural Household Dynamics Project has been provided in Zimbabwe by the British Development Division in Central Africa, UNICEF, and the former Ministry of Lands, Resettlement and Rural Development. Additional support was provided by grants in the United Kingdom from the Nuffield Foundation, the Overseas Development Institute, and the Department for International Development (formerly ODA). Assistance has also been received from the International Food Policy Research Institute, the Food and Agriculture Organization (FAO), the Centre for the Study of African Economies at the University of Oxford, the Free University, Amsterdam, and the Research Board of the University of Zimbabwe.
} 
standard errors, endogeneity, sample selection and fixed, unobserved household characteristics. Section 5 considers the role of initial conditions, while section 6 discusses the distribution of these changes across the sample. Section 7 concludes.

\section{Background to study}

\section{(i) Post-independence land resettlement in Zimbabwe}

Access to land has long been an issue of major economic and political importance in Zimbabwe. Anger at the gross disparities in land ownership between blacks and whites was a major factor motivating armed rebellion against white minority rule. Upon gaining independence, the Government of Zimbabwe announced a wide ranging programme of land reform, designed to redress these severe inequalities. A component of the land reform programme was the resettlement of households on farms previously occupied by white commercial farmers. Initially, the supply of land for resettlement was determined by the availability of areas which had been abandoned during the liberation war and also the general insecurity of European farmers in peripheral areas who were willing to sell. In most cases, these were the commercial farms contiguous to or generally bordering communal areas.

Criteria for selection into these schemes included: being a refugee or other persons displaced by war, including extra-territorial refugees, urban refugees and former inhabitants of protected villages; being unemployed; being a landless resident in a communal area or having insufficient land to maintain themselves and their families (Kinsey, 1982). At the time of settlement, the household heads were also supposed to be married or widowed, aged 25 to 50 and not in formal employment. Families selected for resettlement were assigned to these schemes, and the nucleated villages within them, largely on a random basis. Generally, these criteria seem to have been followed. In this sample, some $90 \%$ of households settled in the early 1980s had been adversely affected by the war for independence in some form or another. Before being resettled, most $(66 \%)$ had been peasant farmers with the remainder being landless laborers on commercial farms, workers in the rural informal sector or wage earners in the urban sector.

Individuals settled on these schemes were required to renounce any claim to land elsewhere in Zimbabwe. They were not given ownership of the land on which they were settled but instead were given permits covering occupancy of homes and for cultivation. Each household was allocated 5 hectares of arable land for cultivation, with the remaining area in each resettlement site being devoted to communal grazing land. Households were also allocated a residential plot within a planned village. In return for this allocation of land, the Zimbabwean government expected male heads of households to be farmers. Until 1992, male household heads were not permitted to work on other farms, nor could they migrate to cities, leaving their wives to work these plots. Although this restriction has been relaxed, with male heads being allowed to work off farm (provided that household farm production is judged satisfactory by local government officials), in this sample agriculture continues to account for at least 80 per cent of household income in non-drought years.

\section{(ii) The sample}

Over the period, 1982-84, one of the authors (Kinsey) undertook a survey of approximately 400 resettled households. The initial sampling frame was all resettlement schemes established in the first two years of the programme in Zimbabwe's three agriculturally most important agro-climatic zones. These are Natural Regions II, III and IV and correspond to areas of moderately high, moderate and restricted agricultural potential. One scheme was selected randomly from each zone: Mupfurudzi in Mashonaland Central (which lies to the north of Harare in NRII), Sengezi 
in Mashonaland East (which lies south east of Harare in NRIII) and Mutanda in Manicaland (which lies south east of Harare, but farther away than Sengezi and in NRIV). Random sampling was then used to select villages within schemes, and in each selected village, an attempt was made to cover all selected households.

These households were first interviewed over the period July-September 1983 to JanuaryMarch 1984. They are located in 20 different villages (Two additional villages were added to the sample in 1993). Just over half (57\%) are found in Mupfurudzi with $18 \%$ located in Mutanda and 25\% found in Sengezi. They were re-interviewed in the first quarter of 1987 and annually, during January to April, from 1992 to 1998. There is remarkably little sample attrition. Approximately $90 \%$ of households interviewed in 1983/84 were re-interviewed in 1997. There is no systematic pattern to the few households that drop out. Some were inadvertently dropped during the resurveys, a few disintegrated (such as those where all adults died) and a small number were evicted by government officials responsible for overseeing these schemes.

Table 1 provides some descriptive statistics for this sample. (The construction of these variables is outlined in the next section.) In real terms, gross crop income rises by just under 200 per cent between 1982/83 and 1995/96. Although households increase significantly in size, the increase in per capita gross incomes, approximately 160 per cent, is impressive in the context of a country in which per capita incomes have been stagnant since 1980. Table 1 also makes clear that rainfall levels were considerably lower in 1982/83 than they were in 1995/96. The former was a drought year, whereas the latter was one of slightly above average rainfall.

Four questions follow. First, to what extent is the difference in incomes between these years is a consequence of differences in rainfall levels? Second, once the rainfall factor is taken into account, what factors explain any remaining changes in crop income. Third, do these income gains accrue to all households or do these data merely capture enormous gains made by a lucky few. Fourth, these comparisons are based on gross crop income. Is it legitimate to make inferences about changes in living standards based on a single component of household income (and one that does not even take into account input costs in crop production)?

A partial answer is provided by other data found in Table 1. It is noteworthy that the stock of capital assets used in crop production, agricultural tools and trained oxen, rise significantly over this period. Livestock holdings, which play an important buffering role during droughts (Kinsey, Burger and Gunning, 1997) also rise significantly. These increases suggest that the increase in per capita gross crop incomes is not driven solely by rainfall considerations, since it is implausible that they could have occurred in the absence of increases in incomes. The fact that virtually all households now own some livestock is suggestive of broadly distributed gains in wealth. To the extent that capital stock is a proxy for permanent income, and permanent income has some relation to consumption, these data also are consistent with an increase in household consumption levels. That said, it is clearly desirable to move beyond suggestive findings. The next sections of this paper address these questions more systematically.

\section{Understanding the causes of changes in income}

This section uses multi-variate analysis to examine the determinants of gross crop incomes and causes of changes in these incomes over time. Denoting $Y$ to be crop income, explanatory variables to be $X$ and parameter estimates, $\boldsymbol{b}$, the determinants of crop income for the agricultural year October 1982 - June 1983 (denoted as "1983") and July 1995 - June 1996 (denoted as "1996"), $e$ to be the disturbance term, yields for the ith household:

$$
\begin{aligned}
& Y_{1983, i}=b_{1983, i}{ }^{\prime} @ \mathbb{X}_{1983, i}+e_{1983, i} \\
& Y_{1996, i}=b_{1996, i}{ }^{\prime} \mathbf{X}_{1996, i}+e_{1996, i}
\end{aligned}
$$


Analysis begins with a description of the variables that comprise $Y$ and $X$, before turning to the results of estimating (1) and (2).

\section{(i) Variable construction}

In order to compare the estimates obtained from these regressions, the dependent and independent variables need to be identical. The 1982/83 survey round contained data on the following: gross revenues from crop production; the stock of agricultural tools; land used in agricultural production; labor input, as measured by the number of people in the household between the ages of 15 and 64; the number of pairs of oxen owned by the household; the number of extension visits the household receives ; and rainfall, by resettlement scheme. All monetary figures are expressed in 1992 Zimbabwe dollars using the CPI as a deflator.

Gross revenues from crop production are calculated by multiplying the physical quantities of output multiplied by their unit price. During each interview, households were asked to report yield, sales and retention, for each crop, for the previous harvest. Unit prices were calculated for each household by dividing total sales value by the quantity sold. Where a household did not sell any of the crop, its total yield was multiplied by the median price received by farmers in this sample. Unfortunately, the data for the 1982/83 agricultural year do not contain any information on the costs of inputs such as hired labor and purchased fertilizer and pesticides. This precludes estimates based on net crop income.

There are eight variables that comprise $X$ : the log real value of agricultural tools; $\log$ available household adult labour; log land used in crop production; the number of ox teams owned by the household; three extension dummies; and rainfall.

Agricultural tools include ox-ploughs, ox carts, cultivator/harrows, ox-planters, water carts, cotton sprayers, wheelbarrows, tractors and tractor equipment, hoes, axes, spades, machetes and slashers. Valuation of these items is a non-trivial exercise. Throughout the years in which these households have been surveyed, respondents have been asked about what items they owned, when they were obtained, how much they paid for them, and how much they would cost today. Answers to these questions revealed two problems. First, a number of households did not remember, and therefore could not report, what they had paid for the item. Second, the prices of virtually identical items were highly variable between households, perhaps due to problems of recall or differences in knowledge regarding current prices. Rather than allowing the price of capital goods to vary across households, a uniform price is imposed. Specifically, the median purchase prices of items both acquired and reported for the crop year 1995/96 were used as a base. (These are assumed to suffer fewer recall problems.) These were deflated using the consumer price index to derive prices for other survey years, including those used here.

This approach does not take into account depreciation. It could be argued that wear and tear on assets reduces their value. Accordingly, depreciation should be deducted from gross investment in order to calculate the increase in capital which is relevant to explaining increases in output. Alternatively, as argued by Scott (1991), a machine that produces the same quantity of output ceteris paribus, year-in year-out cannot be said to have experienced any depreciation. He argues that capital only depreciates when it becomes obsolete. For this reason, he argues that capital stock should be measured in gross terms, not net of depreciation. This argument reflects the situation facing households in the sample. Due to the nature of asset ownership within the sample it would lead to a gross underestimate of the level of capital stock if these items were depreciated. Many households own and still use equipment handed down from previous generations. For example, in 1982/83 over 50 percent of households owned and used an oxplough which was over 10 years old (11 percent of households owned an ox-plough over 30 years 
old). Therefore to measure the effect of capital these circumstances the appropriate measure of capital stock is a gross figure, and not a net figure.

The ideal measure of labor usage would be days worked, by person and activity. Unfortunately, this measure is not available for either of the survey years used here. As a crude proxy, available family labor supply - defined as the number of people in the household between the ages of 15 and 64 - is used. A related input, ownership of pairs of oxen, is included. Pairs of oxen permit fields to be prepared faster using a plough than by the alternative, individuals using hoes. They also allow farmers to improve the timing of planting, by ensuring that fields will be prepared in advance of the early season rains and they typically make it possible to break up the soil to a greater depth.

Visits by extension workers are captured via the inclusion of three dummy variables. These are additive in the sense that 'receives at least two extension visits' dummy captures the marginal effect of a second visit, conditional on the household having received one visit. Finally, levels of rainfall recorded at the nearest station are included as a regressor. There is one rainfall observation per settlement scheme.

A final comment is in order. The rather limited information available for the 1982/83 agricultural year places restrictions on the extent of this analysis. The absence of data on crop inputs restricts analysis to the determinants of gross, rather than net crop income. It is also makes it impossible to estimate profit functions. Further, detailed data on other sources of income are not available for 1982/83 either. In light of this, it is helpful to consider the validity of gross crop income as a measure of the level of household welfare.

With respect to the 1982/83 agricultural year, respondents were asked to rank sources of income in terms of their contribution to total household income. Approximately 80 per cent of households ranked agriculture as the most important source of income, a figure that rises to 93 per cent in the 1985/86 (non-drought) agricultural year. In the case of the 1995/96 data, it is possible to construct a Spearman correlation coefficient that looks at households ranked by both gross crop income and total income (gross crop income less input costs plus net income from wage labor, remittances, gifts and other non-agricultural activities). The coefficient equals 0.90 , and rises to 0.96 if we exclude 17 households experiencing the largest change in rank order. Collectively, these data suggest that gross crop income is a good proxy for total household income.

\section{(ii) Basic results}

There are 396 households in the survey that covers the 1982/83 agricultural year. Largely as a consequence of the drought, 85 do not report any income from crop production. In addition, there is no data on capital stock for 23 households and on household size for 2 households, yielding a sample size of 286 for this year. There are 396 households in the surveys that capture the 1995/96 agricultural year, of which 2 report no crop income, giving a sample size of 394 . These samples are used to generate the results reported below. The obvious selectivity issues are discussed below.

Table 2 presents the estimates of equations (1) and (2) for all households reporting gross crop revenues greater than zero. The dependent variable, together with capital stock, land, labor and rainfall are all in log terms. Standard errors are corrected for heteroscedasticity using the method outlined by Huber (1967) and popularized by White (1980). 
In real terms, the value of gross production increases by just under 200 per cent. ${ }^{2}$ The returns to agricultural tools rise by a factor of three. Returns to land increase by about 60 per cent. The quantity of household labour available has no statistically significant effect on gross crop output, controlling for other factors of production. ${ }^{3}$ By contrast, although the stock of pairs of trained oxen has risen, the impact of this is offset by a reduction in returns to oxen ownership. ${ }^{4}$ In the first survey round, virtually every household receives at least one visit from an agricultural extension officer but relative to the few households receiving no visit, this has no effect on output. In 1994-95, extension coverage is much poorer, but receipt of one visit is associated with an increase in the real value of crop output by 29 per cent. Reassuringly, there is a positive and well measured relationship between rainfall and the value of crop production. Also note that the predictive power of the model is considerably better for the 1995/96 sample and the parameters tend to be estimated with greater precision.

\section{(iii) Decomposing the causes of changes in income}

As already noted, rainfall was considerably lower in 1982/83, by about 45 per cent for the households in this sample. Given the strong relationship between rainfall and output, this undoubtedly accounts for some of the observed change in incomes. However, given the large changes in the values of other variables, and the observed changes in the parameter estimates, it would be useful to separate out the impact of these changes.

Recall that multiplying the coefficients by the means of the explanatory variables generates the mean of the dependent variable. Denote means of the dependent variable as $\bar{y}, \bar{x}$ as a vector of means of right hand side variables, and $\mathbf{b}$ as a vector of parameter estimates. Accordingly:

$$
\begin{aligned}
& \hat{\mathrm{O}}_{1983}=\boldsymbol{b}_{1983}{ }^{\prime} \text { (D) } \\
& \hat{\mathrm{O}}_{1996}=\boldsymbol{b}_{1996} \text { ' (D) } \\
& 1996
\end{aligned}
$$

As Neumark (1988) and others have noted, equations (3) and (4) can be manipulated to yield:

\footnotetext{
${ }^{2}$ The mean of the dependent variable, in log terms, rises from 6.308 to 8.263 . Recall that the difference in logs is approximately equal to the percentage change in value.

\begin{abstract}
${ }^{3}$ A natural interpretation of the labour coefficient in Table 2 is that increasing the family labour force has no impact on output - suggesting a situation of 'surplus labour' for these households. Such a finding sits uneasily beside the fact that few households cultivate all five hectares in any given agricultural year and some complain of labour shortages. However, this 'natural interpretation' is incorrect. Increasing family labour supply has a strong, positive and statistically significant effect on the amount of land these households employ (results available on request). Two observations follow. The correct interpretation of the labour coefficient is that it has no effect on output, conditioning on the other regressors. Put another (slightly inaccurately) way, family labour supply raises output by increasing the amount of land cultivated, but does not have an impact over and above this. Second, if these households faced well functioning labour markets, there should be no relationship between potential household labour supply and the amount of land used by the household. The fact that such a relationship is observed suggests that such an assumption regarding labour markets is unwarranted here. (Our thanks to Duncan Thomas who first alerted us to this point.)
\end{abstract}

\footnotetext{
${ }^{4}$ There is an intriguing explanation for the decline in the coefficient on trained oxen. Just like people, oxen 'learn by doing'. Over time, they become used to the commands of the individual leading them and learn what is required of them. In this sample, as households have accumulated additional oxen, their average age has declined. Consequently, one would expect productivity to fall, precisely what is observed here. (Our thanks to Chris Scott who suggested this interpretation.)
} 


$$
\hat{\mathrm{O}}_{1996}-\hat{\mathrm{O}}_{1983}=\left(\mathrm{O}_{1996}-\mathrm{O}_{1983}\right)^{\prime} \cdot \boldsymbol{b}_{1996}+\left(\boldsymbol{b}_{1996}-\boldsymbol{b}_{1983}\right) \bigotimes_{1983}{ }^{\prime}
$$

Equation (5) shows that the difference between mean gross crop incomes in 1982/83 and 1995/96 equals changes in the level of income generating assets (the first term) multiplied by the return to these assets in 1982/83 plus changes in returns to these assets multiplied by their level in 1982/83 (the second term). Put crudely, the first term captures the collective impact of changes in the accumulation of factors of production whereas the second term captures changes in the productivity of inputs. This is commonly referred to as an Oaxaca decomposition (Oaxaca, 1973). However, note that equations (3) and (4) can also be manipulated to yield:

$$
\hat{\mathrm{o}}_{1996}-\hat{\mathrm{O}}_{1983}=\left(\mathrm{O}_{1996}-\mathrm{O}_{1983}\right)^{\prime} \cdot \boldsymbol{b}_{1983}+\left(\boldsymbol{b}_{1996}-\boldsymbol{b}_{1983}\right) \bigotimes_{1996}{ }^{\prime}
$$

Although conceptually equation (6) looks similar to equation (5), there is no guarantee that it will produce the same results. Following standard practice, both (5) and (6) are used in the results reported below.

Results are reported in Table 3. Note that using either decomposition method yields broadly similar findings. Also note that looking only at the last row, which reports the sums of the impact of changes in endowments and changes in returns to endowments, suggests that changes in levels of the regressors are the principal cause of increased crop incomes. But a more careful examination reveals that this finding is generated entirely by the rainfall and constant terms. Abstracting from the role played by rainfall, it is changes in returns to assets (columns (B) and (D)) - especially those associated with agricultural tools and land - that account for much of the change in gross crop income. ${ }^{5}$

It is worth commenting on the factors that may have led to this increase in returns to assets, particularly tools and land. There are a number of possibilities. First, there is entry by a number of households into the production of higher-value crops such as cotton, groundnuts, and sunflowers. Second, there has been a cumulative capitalization of labor into improving the land. Much of the arable land allocated to the settlers in the early 1980s had lain uncultivated for many years. Given that settlement often occurred just a short period before households would have had to plant their first crops, land thus had to be cleared quickly initially. Inevitably this meant partial clearing was the norm, and very little stumping was done. Without full clearing and thorough stumping, ox-plowing cannot be done efficiently. Fields have been progressively cleared and stumped over the years. In addition, there has been ongoing investments in soil conservation and water control and retention measures. Third, the quality of tools is increasing, as is farmers' knowledge regarding their use. One example of this is the cotton sprayer, designed to spray insecticide to control bollworms. However, farmers are increasingly using the cotton sprayers to apply pre-emergence herbicide and thus achieving significant labor savings for weeding. A second example pertains to the use of ox-drawn ploughs. In the early 1980s, it was not uncommon to see three people working with an ox team and plough: one handling the plough; one leading the

\footnotetext{
${ }^{5}$ Oaxaca and Ransom (1999) issue a cautionary note regarding the contributions of individual variables to the wage decomposition. They note that where several sets of dummy variables are employed, the detailed results of the decomposition will be sensitive to the omitted group. Although their argument is correct, and applies to both dummy and slope parameters, the impact of their critique here is minimized by: a) the presence of only one set of dummy variables in these regressions (see Oaxaca and Ransom, 1999, p. 156); and b) their own finding that in the absence of affine transformations of continuous variables, the role played by these variables is invariant to the choice of the omitted group.
} 
team with a rope; and the third walking alongside with a whip exhorting the oxen to behave and do what is wanted. Fifteen years later, one sees a single man ploughing by himself and controlling the animals entirely through whistles and voice commands. More generally, it is entirely likely that these households have acquired significant 'learning-by doing.' The land these households settled on in the early 1980s was entirely unfamiliar to them. Over time, they will have learnt what crops grow best on which plots, the appropriate methods for growing new crops and so on.

\section{How robust are these results?}

This section considers the finding that increases in gross crop incomes are largely driven by increases in returns to factors of production in light of a number of econometric concerns: calculation of standard errors; endogeneity of right hand side regressors; the role of unobserved, time invariant characteristics; and selectivity issues.

\section{(i) Alternative standard error calculations}

The variance-covariance matrix used to generate the standard errors and $t$ statistics reported in Table 2 uses Huber-White's well-known weighting matrix. However, it has been argued that these estimates can be adversely affected by a small number of outliers in the weighting matrix. Thomas (1994) argues that this can lead, on occasion, to dramatically understating standard errors and therefore overstating levels of significance. Deaton (1997) point to a second area of concern. Households in the same village and the same settlement scheme will share some common characteristics. In a statistical sense, therefore, the household level disturbance terms are not independent.

Table 4 presents three estimates of coefficents' standard errors (reported in terms of the absolute values of their asymptotic t statistics). The first columns of both the 1982/83 and 1995/96 results repeat those results found in Table 2. The second columns report the absolute values of asymptotic $t$ statistics based on the variance-covariance matrix outlined by Mackinnon and White (1985) which is robust in the presence of leverage points. The third columns, based on Rogers (1993) calculates robust standard errors in the presence of intra-cluster correlation at the village level. Two findings emerge. First, the more conservative estimates produced using the MacKinnon-White method produce very small changes in the t statistics. They do not change the results reported in Table 2 at conventional significance levels. Accounting for the clustered nature of the data does not alter in any substantive way, the household level coefficients. Not surprisingly, the $t$ statistic on rainfall falls by dramatically, by about 50 per cent, but remains statistically significant.

\section{(ii) Two stage least squares results}

A striking feature of the results reported in Table 2 is the relatively large coefficient on the land variable. One could make the argument that this a consequence of a failure to recognize that for these households, the amount of land farmed in any one year is a choice variable. (The same argument does not hold for tools, pairs of oxen and the number of adults resident in the household, which all can be regarded as fixed in the short term.) Since the increase in returns to land is a major factor in the increase in gross crop incomes, this critique represents an important challenge to this core finding.

The standard econometric fix to endogeneity concerns is two stage least squares estimation. Its successful application requires: (i) that the instruments be relevant, in the sense that they are correlated with the endogenous variable; and (ii) that the instruments are uncorrelated with the disturbance terms in the structural regression. In the case considered here, it is difficult to think 
of a variable that would affect the household's use of land, but not affect output. Consequently, the approach taken here was to undertake a somewhat mechanistic search of possible correlates of land use. In the 1995/96 data, the number of plots available to the household and the soils on these plots being clay were found to be significant predictors of land. The F statistic testing the hypothesis that these regressors in the first stage regression are jointly zero equals 14.59 , a figure comfortably above the rule of thumb threshold of 10 established by Bound, Jaeger and Baker (1995). These variables also satisfy the over-identification test proposed by Davidson-MacKinnon (1993) on the joint hypothesis that the instruments are uncorrelated with the errors and that the second stage regression is correctly specified.

Based on this finding, these two variables are used as instruments for land and equations (1) and (2) are re-estimated. The results are reported in Table 6. There are three notable features. First, these variables are good instruments for the 1995/96 sample, but not for 1982/83 (see note 4 for the test statistics). In fact, it proved impossible to find any variables that satisfied standard criteria for instruments for the 1982/83 round. Second, the impact of instrumenting is to increase the parameter estimates for land in both years, rendering the returns almost equal. But two stage least squares estimation changes the values of all parameters, not just those on the instrumented variable. Third, the decomposition of the change in income reveals precisely the same pattern uncovered in Table 3. The change in income over this period is largely due to changes in returns to assets. The effect of controlling, albeit imperfectly, for the endogeneity of the land variable is to alter the contributions of various variables to this finding - with increasing returns to agricultural tools now playing a much more important role - but not to overturn this result.

\section{(iii) Selectivity issues}

The sample used to generate the parameter estimates reported in Table 2 is restricted to those households for whom data are available on the dependent variable and on the regressors. As noted, this results in a dramatic reduction in the sample covering the 1982/83 agricultural year. Households reporting zero crop incomes in 1982/83 have, on average, lower levels of capital stock in the form of agricultural tools, utilized less land and have fewer adults. The differences in the mean values for these variables are statistically significant. ${ }^{6}$ As the households reporting zero gross crop incomes are a non-random sub-sample of the survey, the parameter estimates reported above are likely to be biased. Standard econometric 'fixes' to selectivity problems, such as the method suggested by Heckman (1979), are not promising solutions. It is difficult to think of variables that affect the likelihood of obtaining crop output, but do not affect the level of that output. Further the vast literature on selectivity biases increasingly emphasizes how parameter results can be especially sensitive to the selectivity fix.

Accordingly, the approach taken here is to consider the sub-sample of households reporting in both rounds, gross crop income greater than zero in both rounds and data on all regressors. This modestly reduces the sample size for 1982/83 from 284 to 267 . The reduction in sample size is more dramatic for the 1995/96 round, with the sample size falling from 394 to 267 . Table 6 reports the results of the parameter estimates for these sub-samples, together with variable means and the decomposition based on equation (5). ${ }^{7}$ As in Table 2, standard errors and hence $\mathrm{t}$ statistics are computed using the Huber-White method. The alternative methods described above

\footnotetext{
${ }^{6}$ Further details are available on request.

${ }^{7}$ The decomposition based on (6) yields almost identical results.
} 
yield similar results. Not surprisingly, the 1982/83 results differ little from those reported above. The 1995/96 results indicate that for this sub-sample, returns to agricultural tools are lower than they are for the full sample, but this effect is somewhat offset by higher returns to land and trained oxen. The decomposition reveals exactly the same pattern reported in Table 3. Abstracting from the impact of rainfall and the intercept terms, only $19.2 \%$ of the difference in mean crop incomes are attributable to differences in levels of assets. Crop income growth is largely attributable to increased returns to these assets. Selectivity concerns do not alter this core finding.

\section{(iv) The role of fixed, unobservable characteristics}

A final econometric concern is that these parameter estimates may be biased by the exclusion of fixed, unobserved characteristics that affect farm production. For example, more skillful farmers may be able to bring more land into production in a given time period or may have better access to agricultural extension workers. The sub-sample of households who appear in both survey rounds are an appropriate group to consider this issue. As before, the dependent variable is gross crop income. Regressors are those described above, together with terms capturing the interaction between these explanatory variables and a dummy equaling one if the observation is drawn from the 1982/83 survey round. These interaction terms are included to capture the change in returns to assets that has already been noted. The prior expectation is that these should be negative for tools, land and extension and positive for trained oxen, reflecting the pattern described above. The pooled sample is estimated using ordinary least squares with no account taken of the role of unobservables, random effects and household fixed effects.

In order to save space, full results are not reported here. (These are available on request.) In brief, a Breusch-Pagan test comparing random effects against an OLS model with no account taken of household level unobservables produces a chi-squared statistic with a prob value of only 0.27. A Hausman test, comparing the random and fixed effects estimates produces a chi squared statistic with a prob value of only 0.32 . The F statistic on the household level unobservables has a prob value of 0.093 . At conventional significance levels, it appears that the null hypothesis, that these results are not affected by household level unobservables, cannot be rejected. Further, all interaction terms have their predicted signs, with the coefficients on the land and 'at least one extension visit' interaction terms significantly different from zero. Recall from Table 3 that these variables accounted for about 75 per cent of the difference in mean incomes attributable to factors other than rainfall. Hence, concerns regarding the role of fixed, unobserved household characteristics do not appear to alter the core results found so far.

\section{The role of initial conditions}

The results reported thus far take no account of significant differences in other characteristics at the time of resettlement. For example, about 40 per cent of household heads had less than four years of schooling and about 38 per cent had never been visited by an extension worker. Yet, one might believe such factors to be important. To the extent that they are relevant determinants of crop income, their omission suggests that are results are vulnerable to concerns regarding omitted variable bias. The large literature on the determinants of cross-country growth stresses that more favourable initial conditions, in terms of say human or social capital, allows countries to maintain higher rates of growth over time. Further, suppose that initial conditions are an important, persistent determinant of crop incomes. This would suggest that the distribution of incomes over time would become increasingly unequal as advantaged households would experience more rapid increases in incomes, thus producing a increasingly unequal distribution of incomes over time. 
Denoting fixed initial conditions as $\mathrm{Z}_{1984}$, their associated parameter estimates as $z$, and suppressing the $i$ subscript, equations (1) and (2) can be re-written as:

$$
\begin{aligned}
& Y_{1984}=\boldsymbol{b}_{1984}{ }^{\prime} @ \mathrm{X}_{1984}+z_{1984}{ }^{\prime} \bigotimes_{1984}+e_{1984} \\
& \text { and } \\
& Y_{1996}=b_{1996}{ }^{\prime} @ \mathbb{X}_{1996}+z_{1996}{ }^{\prime} @ Z_{1984}+e_{1996}
\end{aligned}
$$

Table 7 reports the results of including selected initial conditions to equations (1) and (2). These are divided into three categories: initial human capital (years of education of household head; household head did 'skilled' work prior to being resettled; household received at least one extension visit prior to being resettled); location (lived in protected village; lived in town; lived in communal area); and social capital (at least one household member belonged to a political organization). Before discussing the results of these regressors, it is helpful to note the large number of variables that were included in preliminary runs, but failed to have any explanatory power. Those relating to human capital included: dummy variables reflecting different levels of schooling attainment by the head; average education levels of all household members excluding the head; and dummy variables reflecting different average household schooling attainment levels. Dummy variables were created describing the activities the household head was engaged in immediately prior to becoming a settler including: whether the head was farming; working as a skilled agricultural worker; a skilled manual laborer; an unskilled laborer; a clerk; involved in domestic service; or serving in the army. Dummies were also tried

for the condition that the household was in at the end of the war, these included: whether the head was unemployed; had house or crops destroyed; cattle killed or stolen; or

reported 'not much affected'. Other variables relating to the social relationships that did not have explanatory power were dummies created for the type of organization that households belonged to including: farmers organizations; specialist groups for example, a youth or woman's group; and local or national political organizations. Other variables included a measure of attendance in groups, whether anyone in the household held an office, and the perceived benefits of belonging to such organizations. Participation in organizations in the area of origin was also considered. Finally, a set of variables was created to reflect whether the household had come with other families from the same home area, if so, whether they lived nearby, or helped each other. None of these proved to be significant.

Table 7 indicates that the parameter estimates on tools, land, labour, oxen and extension are close to those reported in Table 2, suggesting that the core results are not contaminated by the omission of these variables. Further, a number of initial condition variables that are significant in 1982/83, such as previously doing skilled work, having previously received extension advice and having come from a town, have no statistically significant impact on incomes in 1995/96. This suggests that households advantaged in some regard at the time of resettlement initially obtain higher incomes, but this effect disappears over time.

There is one striking exception. Households who lived in a 'protected village' during the war for independence obtained higher incomes both in 1982/83 and 1995/96. Protected villages were a creation of the white minority government during the war for independence. In areas where armed conflict was most prevalent, individual households were forcibly relocated from their homesteads to central sites, referred to as "keeps". Individuals were permitted to venture from these areas during the day but were required to return to these localities before nightfall. It is widely acknowledged that the dislocation and repression associated with this forced relocation 
made living in these protected villages a deeply unpleasant experience but one that may have also fostered a breakdown in traditional values and compelled education and cooperation.

The impact of having lived in a protected village prior to resettlement on gross crop incomes is large, raising them by more than 40 per cent in both years. One possibility is that this variable is capturing some other factor correlated with this characteristic. In particular, all households reporting having lived in a protected village prior to resettlement are located in Mupfurudzi, agro-climatically the area best suited to agriculture. ${ }^{8}$ In regressions not reported here, these initial conditions variables were re-estimated with the rainfall variable replaced with dummy variables for resettlement schemes. ${ }^{9}$ The coefficients on the protected village variables fall by about 50 per cent in magnitude and is no longer significant in the 1982/83 sample. However, it retains some explanatory power in the 1995/96 data, with a t statistic of 1.89. This suggests that this variable is picking up something more than a pure location effect. It may be that this shared experience generated a sense of cohesiveness and common purpose consistent with the more general notion of social capital.

\section{Income changes and changes in poverty}

A fundamental finding of this study, robust to a number of econometric concerns, is that significant income growth has occurred in these resettlement households even after the drought conditions of the early 1980s have been taken into account. An important factor in this process has been improved returns to factors of production. However, there can be no presumption that these income gains necessarily translate into reductions in poverty as measured in terms of consumption. It might be the case that the largest gains are concentrated amongst a few better-off households. Gross crop income may be a poor correlate of total household income. Finally, the correlation between incomes and consumption may be weak.

An ideal way of examining this issue would be to utilize consumption data for both periods, and after taking into account the impact of the drought in the early 1980s, looking at the incidence and severity of poverty. Unfortunately such data are not available. There are, however, a number of inferential points that can be made.

Figure 1 graphs kernel density estimates obtained using an Epanechnikov kernel and optimal bandwidth. Deaton (1997) describes this technique in detail. Put rather crudely, Figure 1 shows the distribution of the log of real per capita gross crop income. The curves can be thought of as histograms in which the 'width' of each bars is narrowed and their tops joined together. The horizontal axis gives the value of this variable, the vertical axis the percentage of households to which that value applies. It shows a dramatic rightward shift in the levels of log real per capita crop incomes, even after excluding the many households in the 1982/83 sample who reported zero crop income. The distribution also becomes more noticeably peaked, suggesting that crop income inequality is diminishing. Estimated Gini coefficients support this interpretation, falling from 0.58 in 1982/83 to 0.49 is $1995 / 96$. But one could argue that this

\footnotetext{
${ }^{8}$ A logical extension to this hypothesis would be that those who suffered most during the war were favoured in the resettlement process in terms of the amount or quality of land that they received. This is unlikely to be correct. Both arable and residential plots were allocated through random draws specifically to avoid any chance of favouritism.

${ }^{9}$ As there is only one observation on rainfall per resettlement scheme, it is not possible to include both rainfall
and scheme dummies in the same model.
} 
shift is driven by the drought conditions of the early 1980s that were not present in the good rainfall year of 1995/96.

Table 8 takes this possibility into account. Based on the regression coefficients reported in Table 2, gross crop incomes are predicted for each household for both years, excluding the impact of rainfall and the constant terms. From these, growth rates are calculated and tabulated by the households gross per capita crop income rank in 1982/83. There are three key findings. First, growth rates are positive for all deciles. Second, growth rates appear slightly higher for households that are predicted to be initially poorer, suggesting convergence of gross crop incomes over time. This finding is consistent with the results reported above that initial conditions do not have, on the whole, persistent effects on gross crop incomes. Third, only one household, in the top decile, reports a reduction in per capita gross crop incomes. These findings suggest that it is highly likely that the concern that growth has been restricted to a few households is unfounded. Rather, households that were poorer in 1982/83 appear to have experienced the most rapid growth in crop incomes.

The correlation between gross crop income and total household income was explored in section 2. There it was argued that these two measures are highly correlated in this sample. Hence, the final issue is the link between income and consumption. One might suspect that this link would be weakened if there were well functioning credit markets which allowed households to follow a consumption path independent of incomes. This issue has been discussed by Kinsey, Gunning and Burger (1997) who examine household responses to the 1991/92 and 1994/95 droughts. This study finds that few households had access to credit markets for the purposes of consumption smoothing and that many reported reducing the frequency of meals, a coping strategy indicative of an inability to maintain consumption levels. Such findings, as Morduch (forthcoming) indicates, are consistent with the view that consumption tracks income. Accordingly, it would seem defensible to claim that the rise in income across all households has led to a rise in consumption and a fall in poverty.

\section{Conclusions}

This examination of income dynamics amongst resettlement households in Zimbabwe has produced four core findings: (i) there has been an impressive accumulation of assets by these households; (ii) while this accumulation has played a role in increases in crop income, it appears that increases in returns to these assets have been especially important in generating the dramatic increase in crop incomes observed in these households. This finding is robust to a wide variety of econometric concerns; (iii) differences in initial conditions across these households, such as previous farming experience, have few persistent effects. Although some of these variables affect output in the first year of our sample, their impact is virtually non-existent by 1995/96; (iv) growth in incomes has been shared across all households, with the largest percentage increases in predicted incomes recorded by households that had the lowest predicted incomes at the beginning of the survey.

These findings are of value in their own right as there are few studies that examine the dynamics of household income change over such a long period of time. They also contribute to the debate over the merits of land redistribution, both in Zimbabwe and elsewhere in the developing world.

An early paper on resettlement in Zimbabwe was entitled, 'Forever gained: Resettlement and land policy in the context of national development in Zimbabwe' (Kinsey, 1982). The first part of the title of that paper, and this one, is taken from a song which rises from the grave of Mkwati, prophet and hero, in Stanlake Samkange's novel Year of the uprising. Mkwati (and 
Samkange) was urging Zimbabweans to return to their country when they could say: "This is the day, this is the hour / The spirits have risen again, / And from our land from white power / Forever gained." This paper has revisited 'forever gained' in several senses. Literally, it reports the results of revisiting households who obtained land formerly occupied by white farmers in the aftermath of Zimbabwe's transition to majority rule. More substantively, it is about revisiting the vision of land resettlement as means of alleviating poverty in rural Zimbabwe. The original objectives of this programme included: (i) extending and improving the base for productive agriculture in the peasant farming sector; (ii) improving the level of living of the largest and poorest sector of the population; (iii) providing, at the lower end of the scale, opportunities for people who have no land; (iv) bringing abandoned or underutilized land into full production; and (v) achieving progress in a country that has only recently emerged from the turmoil of war (Zimbabwe, 1980). The official government critique of resettlement (Zimbabwe, 1993) takes the view that the programme has failed to have a positive impact on agricultural productivity and rural incomes. The findings of this study question this view. For these households, it may be correct to claim that "forever" was gained. ${ }^{10}$

\section{References}

Bound, J., D. Jaeger and R. Baker, 1995, Problems with instrumental variables estimation when the correlation between the instruments and the endogenous explanatory variables is weak, Journal of the American Statistical Association, Vol. 90, pp. 443-450.

Davidson, R. and J. MacKinnon, 1993, Estimation and inference in econometrics, New York: Oxford University Press.

Deaton, A., 1997, The analysis of household surveys, Baltimore: Johns Hopkins University Press.

Heckman, J., 1979, Sample selection bias as specification error, Econometrica Vol. 47, pp. 153161.

Huber, P., 1967, The behavior of maximum likelihood estimates under non-standard conditions in Proceedings of the Fifth Berkeley Symposium in Mathematical Statistics and Probability, Berkeley CA: University of California Press.

Kinsey, B, 1982, Forever gained: Resettlement and land policy in the context of national development in Zimbabwe, Africa, Vol. 52, pp. 92-113.

Kinsey, B., K. Burger and J. Gunning, 1998, Coping with drought in Zimbabwe: Survey evidence on responses of rural households to risk, World Development, Vol. 26, pp. 89-110.

\footnotetext{
${ }^{10}$ Assessing the full merits of this model of land redistribution takes us beyond the scope of this paper. It is helpful to note the following. Over the period considered here, per capita GNP in real Zimbabwe dollars fell by 7 per cent. Within agriculture, livestock production is virtually stagnant. The best direct comparison between this sample and the rest of Zimbabwe relates to crop production. Nationally, this rose by 94 per cent between 1982/83 and 1995/96, an impressive figure but significantly less that the 195 per cent increase in real gross crop income obtained by these households. National figures are taken from World Bank (1998).
} 
MacKinnon, J. and H. White., 1985, Some heteroscedasticity consistent covariance matrix estimators with improved finite sample properties, Journal of Econometrics, Vol. 29, pp. 305325 .

Morduch, J. forthcoming. Between the market and state: Can informal insurance patch the safety net? World Bank Research Observer.

Neumark, D., 1988, Employers' discriminatory behavior and the estimation of wage discrimination, Journal of Human Resources, Vol. 23, pp. 279-295.

Oaxaca, R., 1973, Male-female wage differentials in urban labor markets, International Economic Review, Vol. 14, pp. 693-709.

Oaxaca, R. and M. Ransom, 1999, Identification in detailed wage decompositions. Review of Economics and Statistics, Vol. 81, No. 1, pp. 154-157.

Levine, R. and D. Renelt, 1992, A sensitivity analysis of cross-country growth regressions, American Economic Review, Vol. 82, pp. 942-963.

Rogers, W., 1993, Regression standard errors in clustered samples, STATA Technical Bulletin, Vol. 13, pp. 19-23.

Salai-i-Martin, X., 1997, I just ran two million regressions, American Economic Review, Papers and Proceedings, Vol. 87, pp. 178-183.

Scott, M., 1989, A new view of economic growth. Oxford: Clarendon Press.

Thomas, D., 1994, Like father, like son: Like mother, like daughter: Parental resources and child height, Journal of Human Resources, Vol. 29, pp. 950-988.

White, H., 1980, A heteroscedasticity-consistent covariance matrix and a direct test for heteroscedasticity, Econometrica, Vol. 48, pp. 817-838.

World Bank, 1998, World Development Indicators (CD-ROM), Washington: World Bank.

Zimbabwe, Government of. 1980. Resettlement policies and procedures. Harare: Ministry of Lands, Resettlement and Rural Development.

Zimbabwe, Government of. 1993. Value for money project (special report) of the Comptroller and Auditor-General on the land acquisition and resettlement programme. Harare: Office of the Comptroller and Auditor-General. 
Table 1: Descriptive statistics

\begin{tabular}{|l|l|l|}
\hline & $1982 / 83$ & $1995 / 96$ \\
\hline Log gross crop income & 6.31 & 8.26 \\
\hline Log household size & 1.89 & 2.20 \\
\hline Log per capita gross crop income & 4.42 & 6.06 \\
\hline Log number of adults & 1.05 & 1.52 \\
\hline Log rainfall & 6.19 & 6.64 \\
\hline & & \\
\hline Log land utilized & 1.92 & 2.07 \\
\hline Log agricultural tools & 7.16 & 7.88 \\
\hline Number oxen pairs & 0.77 & 1.27 \\
\hline Receives at least one extension visit & 0.94 & 0.62 \\
\hline Receives at least two extension visits & 0.84 & 0.42 \\
\hline $\begin{array}{l}\text { Receives at least three or more } \\
\text { extension visits }\end{array}$ & 0.77 & 0.29 \\
\hline & 65.0 & 10.3 \\
\hline $\begin{array}{l}\text { Percentage of households owning } \\
\text { livestock }\end{array}$ & 4.1 & 90.1 \\
\hline Mean herd size & & \\
\hline
\end{tabular}

Note

1. Income figures for $1982 / 83$ are restricted to households reporting positive gross crop income.

2. Livestock includes the number of bulls, cows, heifers, calves and oxen. 
Table 2: Determinants of log real gross crop income: 1982/83 and 1995/96

\begin{tabular}{|l|l|l|}
\hline & $1982 / 83$ & $1995 / 96$ \\
\hline Log agricultural tools & $\begin{array}{l}0.090 \\
(0.988)\end{array}$ & $\begin{array}{l}0.255 \\
(3.557)^{* *}\end{array}$ \\
\hline $\begin{array}{l}\text { Log labor } \\
\text { (number of adults) }\end{array}$ & $\begin{array}{l}-0.046 \\
(0.362)\end{array}$ & $\begin{array}{l}-0.007 \\
(0.100)\end{array}$ \\
\hline Log land utilized & $\begin{array}{l}0.792 \\
(5.631)^{* *}\end{array}$ & $\begin{array}{l}1.269 \\
(13.206)^{* *}\end{array}$ \\
\hline Number oxen pairs & $\begin{array}{l}0.274 \\
(3.454)^{* *}\end{array}$ & $\begin{array}{l}0.099 \\
(2.825)^{* *}\end{array}$ \\
\hline Receives at least one extension visit & $\begin{array}{l}-0.168 \\
(0.579)\end{array}$ & $\begin{array}{l}0.291 \\
(2.742)^{* *}\end{array}$ \\
\hline Receives at least two extension visits & $\begin{array}{l}-0.064 \\
(0.210)\end{array}$ & $\begin{array}{l}0.047 \\
(0.390)\end{array}$ \\
\hline Receives at least three or more & $\begin{array}{l}0.122 \\
\text { extension visits }\end{array}$ & -0.138 \\
& $(0.496)$ & $(1.304)$ \\
\hline Ln rainfall & $\begin{array}{l}4.286 \\
(7.612)^{* *}\end{array}$ & $\begin{array}{l}3.609 \\
(6.972)^{* *}\end{array}$ \\
\hline Constant & -22.438 & -20.608 \\
$(6.452)^{* *}$ & $(6.100)^{* *}$ \\
\hline & & 8.263 \\
\hline Mean of dependent variable & 6.308 & $60.59^{* *}$ \\
\hline F statistic & $14.75^{* *}$ & 0.525 \\
\hline R2 & 0.334 & \\
\hline & & \\
\hline
\end{tabular}

Notes:

1. Dependent variable is log of real gross crop income.

2. Omitted category is household receives no extension visits.

3. Absolute values of $\mathrm{t}$ statistics in parentheses. * significant at the $10 \%$ level; ** significant at the $5 \%$ level.

4. Sample size is 286 for 1982/83 and 394 for 1995/96. 
Table 3: Decomposition of changes in log real gross crop income

\begin{tabular}{|c|c|c|c|c|c|c|}
\hline & \multicolumn{3}{|c|}{ Decomposition based on equation (5) } & \multicolumn{3}{|c|}{ Decomposition based on equation (6) } \\
\hline & $\begin{array}{c}\left(\bar{x}_{1996}-\bar{x}_{1983}\right) \cdot b_{1996} \\
(\mathrm{~A})\end{array}$ & $\begin{array}{c}\left(\mathrm{b}_{1996}-\mathrm{b}_{1983}\right) \cdot \bar{x}_{1983} \\
(\mathrm{~B})\end{array}$ & $(\mathrm{A})+(\mathrm{B})$ & $\begin{array}{c}\left(\bar{x}_{1996}-\bar{x}_{1983}\right) \cdot b_{1983} \\
\text { (C) }\end{array}$ & $\begin{array}{c}\left(b_{1996}-b_{1983}\right) \cdot \bar{x}_{1996} \\
\text { (D) }\end{array}$ & $(\mathrm{C})+(\mathrm{D})$ \\
\hline Log agricultural tools & 0.183 & 1.181 & 1.364 & 0.065 & 1.300 & 1.365 \\
\hline Log labor & -0.003 & 0.040 & 0.036 & -0.022 & 0.058 & 0.037 \\
\hline Log land & 0.191 & 0.916 & 1.107 & 0.119 & 0.988 & 1.107 \\
\hline Number oxen pairs & 0.049 & -0.135 & -0.085 & 0.137 & -0.222 & -0.085 \\
\hline $\begin{array}{l}\text { Receives at least one } \\
\text { extension visit }\end{array}$ & -0.094 & 0.433 & 0.339 & 0.054 & 0.285 & 0.339 \\
\hline $\begin{array}{l}\text { Receives at least two } \\
\text { extension visits }\end{array}$ & -0.019 & 0.093 & 0.074 & 0.026 & 0.047 & 0.074 \\
\hline $\begin{array}{l}\text { Receives at least } \\
\text { three or more } \\
\text { extension visits }\end{array}$ & 0.065 & -0.199 & -0.134 & -0.058 & -0.076 & -0.134 \\
\hline $\begin{array}{l}\text { Column sums for } \\
\text { these regressors }\end{array}$ & $\begin{array}{c}0.372 \\
(13.8 \%)\end{array}$ & $\begin{array}{c}2.330 \\
(86.2 \%)\end{array}$ & 2.702 & $\begin{array}{c}0.322 \\
(11.9 \%)\end{array}$ & $\begin{array}{r}2.380 \\
(88.1 \%)\end{array}$ & 2.702 \\
\hline $\begin{array}{l}\text { Effect of rainfall and } \\
\text { constant }\end{array}$ & 1.610 & -2.357 & -0.747 & 1.912 & -2.659 & -0.747 \\
\hline Totals & $\begin{array}{c}1.982 \\
(101.4 \%)\end{array}$ & $\begin{array}{c}-0.027 \\
(-1.4 \%)\end{array}$ & 1.955 & $\begin{array}{r}2.234 \\
(114.3 \%)\end{array}$ & $\begin{array}{r}-0.279 \\
(-14.3 \%)\end{array}$ & 1.955 \\
\hline
\end{tabular}


Table 4: Absolute values of $\mathrm{t}$ statistics using different method for constructing standard errors for regressors

\begin{tabular}{|c|c|c|c|c|c|c|}
\hline & \multicolumn{3}{|c|}{$1982 / 83$} & \multicolumn{3}{|c|}{$1995 / 96$} \\
\hline & Huber-White & $\begin{array}{l}\text { MacKinnon- } \\
\text { White }\end{array}$ & $\begin{array}{l}\text { Cluster } \\
\text { (village) }\end{array}$ & Huber-White & $\begin{array}{l}\text { MacKinnon - } \\
\text { White }\end{array}$ & $\begin{array}{c}\text { Cluster } \\
\text { (village) }\end{array}$ \\
\hline $\begin{array}{l}\text { Log agricultural } \\
\text { tools }\end{array}$ & 0.988 & 0.950 & 1.558 & $3.557 * *$ & $3.456^{* *}$ & $2.964 * *$ \\
\hline Log labor & -0.362 & -0.352 & -0.464 & -0.100 & -0.098 & -0.091 \\
\hline Log land & $5.631 * *$ & $5.473 * *$ & $6.213 * *$ & $13.206^{* *}$ & $13.022 * *$ & $9.939 * *$ \\
\hline $\begin{array}{l}\text { Number oxen } \\
\text { pairs }\end{array}$ & $3.454 * *$ & $3.331 * *$ & $2.579 * *$ & $2.825^{* *}$ & $2.599 * *$ & $2.530 * *$ \\
\hline $\begin{array}{l}\text { Receives at least } \\
\text { one extension } \\
\text { visit }\end{array}$ & -0.579 & -0.545 & -0.553 & $2.742 * *$ & $2.712 * *$ & $2.575^{* *}$ \\
\hline $\begin{array}{l}\text { Receives at least } \\
\text { two extension } \\
\text { visits }\end{array}$ & -0.210 & -0.200 & -0.249 & 0.390 & 0.383 & 0.324 \\
\hline $\begin{array}{l}\text { Receives at least } \\
\text { three or more } \\
\text { extension visits }\end{array}$ & 0.496 & 0.472 & 0.617 & -1.304 & -1.274 & -1.410 \\
\hline Ln rainfall & $7.612 * *$ & $7.340 * *$ & $4.435^{* *}$ & $6.972 * *$ & $6.828 * *$ & $4.017 * *$ \\
\hline
\end{tabular}

Notes:

1. Dependent variable is log of real gross crop income.

2. Specification, sample sizes and omitted group as per Table 2.

3. Absolute values of $\mathrm{t}$ statistics in parentheses. * significant at the $10 \%$ level; ** significant at the $5 \%$ level. 
Table 5: $\quad$ Two stage least squares estimates of determinants of log real gross crop income: 1982/83 and 1995/96

\begin{tabular}{|c|c|c|c|c|c|}
\hline & $1982 / 83$ & $1995 / 96$ & \multicolumn{3}{|c|}{ Decomposition based on equation (5) } \\
\hline & $\begin{array}{c}\text { Parameter } \\
\text { estimates }\end{array}$ & $\begin{array}{l}\text { Parameter } \\
\text { estimates }\end{array}$ & $\begin{array}{c}\left(\bar{x}_{1996}-\bar{x}_{1983}\right) \\
\cdot b_{1996} \\
(A)\end{array}$ & $\begin{array}{c}\left(b_{1996}-b_{1983}\right) \cdot \bar{x} \\
1983 \\
\text { (B) }\end{array}$ & $(\mathrm{A})+(\mathrm{B})$ \\
\hline $\begin{array}{l}\text { Log agricultural } \\
\text { tools }\end{array}$ & $\begin{array}{l}-0.036 \\
(0.190)\end{array}$ & $\begin{array}{l}0.174 \\
(1.931)^{*}\end{array}$ & 0.125 & 1.501 & 1.626 \\
\hline Log labor & $\begin{array}{l}-0.021 \\
(0.140)\end{array}$ & $\begin{array}{l}-0.163 \\
(1.448)\end{array}$ & -0.077 & -0.148 & -0.225 \\
\hline Log land & $\begin{array}{l}2.062 \\
(1.690)^{*}\end{array}$ & $\begin{array}{l}2.129 \\
(5.420)^{* *}\end{array}$ & 0.321 & 0.129 & 0.450 \\
\hline Number oxen pairs & $\begin{array}{c}0.181 \\
(1.599)\end{array}$ & $\begin{array}{c}0.015 \\
(0.316)\end{array}$ & 0.007 & -0.128 & -0.121 \\
\hline $\begin{array}{l}\text { Receives at least } \\
\text { one extension visit }\end{array}$ & $\begin{array}{l}-0.529 \\
(1.277)\end{array}$ & $\begin{array}{l}0.252 \\
(2.121)^{* *}\end{array}$ & -0.081 & 0.738 & 0.657 \\
\hline $\begin{array}{l}\text { Receives at least } \\
\text { two extension visits }\end{array}$ & $\begin{array}{c}0.124 \\
(0.341)\end{array}$ & $\begin{array}{l}-0.041 \\
(0.276)\end{array}$ & 0.017 & -0.138 & -0.121 \\
\hline $\begin{array}{l}\text { Receives at least } \\
\text { three or more } \\
\text { extension visits }\end{array}$ & $\begin{array}{c}0.013 \\
(0.042)\end{array}$ & $\begin{array}{l}-0.136 \\
(0.985)\end{array}$ & 0.064 & -0.114 & -0.050 \\
\hline $\begin{array}{l}\text { Column sums for } \\
\text { these regressors }\end{array}$ & & & 0.376 & 1.840 & 2.216 \\
\hline Ln rainfall & $\begin{array}{l}4.878 \\
(6.175)^{* *}\end{array}$ & $\begin{array}{l}4.993 \\
(6.750)^{* *}\end{array}$ & \multirow[t]{2}{*}{2.228} & \multirow[t]{2}{*}{-2.468} & \multirow[t]{2}{*}{-0.240} \\
\hline Constant & $\begin{array}{l}-27.358 \\
(4.775)^{* *}\end{array}$ & $\begin{array}{l}-30.539 \\
(6.114)^{* *}\end{array}$ & & & \\
\hline F statistic & $10.27 * *$ & $26.00 * *$ & & & \\
\hline
\end{tabular}

Notes:

1. Dependent variable is log of real gross crop income.

2. Specification, sample sizes and omitted group as per Table 2.

3. Absolute values of $\mathrm{t}$ statistics in parentheses. * significant at the $10 \%$ level; significant at the $5 \%$ level.

4. Instruments for land are soil type is clay and number of plots allocated to household. F tests on excluded instruments are $\mathrm{F}(2,322)=14.59 * *$ for $1995 / 96$ and $\mathrm{F}(2,246)=2.55 *$ for $1982 / 83$. Davidson-MacKinnon overidentification tests on joint hypotheses that instruments are uncorrelated with errors and model is correctly specified are Chi-squared $(1)=2.64($ prob value $=0.104$ ) for $1995 / 96$ and Chi-squared $(1)=1.87$ (prob value $=0.171$ ) for 1982/83. F tests on inclusion of predicted residual from first stage regression on structural model (equivalent to Hausman test) are $\mathrm{F}(1,322)=7.09 * *$ for $1995 / 96$ and $\mathrm{F}(1,246)=1.38$ for $1982 / 83$. 
Table 6: Determinants of log real gross crop income 1982/83 and 1995/96 and decomposition of changes using full samples and only households with gross crop income greater than zero in both survey rounds

\begin{tabular}{|c|c|c|c|c|c|c|c|c|c|c|c|}
\hline & \multicolumn{4}{|c|}{$1982 / 83$} & \multicolumn{4}{|c|}{ 1995/96 } & \multicolumn{3}{|c|}{ Decomposition based on equation (5) } \\
\hline & \multicolumn{2}{|c|}{ Parameter estimates } & \multicolumn{2}{|c|}{ Means } & \multicolumn{2}{|c|}{ Parameter estimates } & \multicolumn{2}{|c|}{ Means } & \multirow{2}{*}{$\begin{array}{l}\left(\bar{x}_{1996}-\bar{x}_{1983}\right) \\
\cdot \mathrm{b}_{1996}(\mathrm{~A})\end{array}$} & \multirow{2}{*}{$\begin{array}{l}\left(b_{1996}-b_{1983}\right) \cdot \bar{x} \\
1983 \\
\text { (B) }\end{array}$} & \multirow[t]{2}{*}{$(\mathrm{A})+(\mathrm{B})$} \\
\hline & Sample 1 & Sample 2 & Sample 1 & Sample 2 & Sample 1 & Sample 2 & Sample 1 & Sample 2 & & & \\
\hline Log agricultural tools & $\begin{array}{c}0.090 \\
(0.988)\end{array}$ & $\begin{array}{c}0.098 \\
(1.063)\end{array}$ & 7.162 & 7.172 & $\begin{array}{l}0.255 \\
(3.557)^{* *}\end{array}$ & $\begin{array}{l}0.146 \\
(1.666)^{*}\end{array}$ & 7.880 & 7.994 & 0.120 & 0.348 & 0.468 \\
\hline Log labor & $\begin{array}{l}-0.046 \\
(0.362)\end{array}$ & $\begin{array}{l}-0.081 \\
(0.649)\end{array}$ & 1.046 & 1.033 & $\begin{array}{l}-0.007 \\
(0.100)\end{array}$ & $\begin{array}{c}0.094 \\
(1.061)\end{array}$ & 1.518 & 1.551 & 0.049 & 0.180 & 0.229 \\
\hline Log land & $\begin{array}{l}0.792 \\
(5.631)^{* *}\end{array}$ & $\begin{array}{c}0.839 \\
(5.725)\end{array}$ & 1.921 & 1.925 & $\begin{array}{c}1.269 \\
(13.206)^{*} \\
*\end{array}$ & $\begin{array}{c}1.388 \\
(11.845)^{*} \\
*\end{array}$ & 2.071 & 2.088 & 0.227 & 1.058 & 1.285 \\
\hline Number oxen pairs & $\begin{array}{l}0.274 \\
(3.454)^{* *}\end{array}$ & $\begin{array}{c}0.260 \\
(3.154)\end{array}$ & 0.771 & 0.773 & $\begin{array}{l}0.099 \\
(2.825)^{* *}\end{array}$ & $\begin{array}{l}0.150 \\
(3.839)^{* *}\end{array}$ & 1.269 & 1.333 & 0.084 & -0.085 & -0.001 \\
\hline $\begin{array}{l}\text { Receives at least one } \\
\text { extension visit }\end{array}$ & $\begin{array}{l}-0.168 \\
(0.579)\end{array}$ & $\begin{array}{l}-0.319 \\
(0.998)\end{array}$ & 0.944 & 0.947 & $\begin{array}{l}0.291 \\
(2.742) * *\end{array}$ & $\begin{array}{l}0.273 \\
(2.072)^{* *}\end{array}$ & 0.622 & 0.614 & -0.091 & 0.561 & 0.470 \\
\hline $\begin{array}{l}\text { Receives at least two } \\
\text { extension visits }\end{array}$ & $\begin{array}{l}-0.064 \\
(0.210)\end{array}$ & $\begin{array}{l}-0.020 \\
(0.062)\end{array}$ & 0.836 & 0.854 & $\begin{array}{c}0.047 \\
(0.390)\end{array}$ & $\begin{array}{l}-0.049 \\
(0.334)\end{array}$ & 0.424 & 0.401 & 0.022 & -0.025 & -0.002 \\
\hline $\begin{array}{l}\text { Receives at least three } \\
\text { or more extension visits }\end{array}$ & $\begin{array}{c}0.122 \\
(0.496)\end{array}$ & $\begin{array}{c}0.119 \\
(0.462)\end{array}$ & 0.766 & 0.783 & $\begin{array}{l}-0.138 \\
(1.304)\end{array}$ & $\begin{array}{l}-0.076 \\
(0.609)\end{array}$ & 0.294 & 0.262 & 0.040 & -0.153 & -0.114 \\
\hline Ln rainfall & $\begin{array}{l}4.286 \\
(7.612)^{* *}\end{array}$ & $\begin{array}{l}4.398 \\
(7.624)\end{array}$ & 6.191 & 6.195 & $\begin{array}{l}3.609 \\
(6.972) * *\end{array}$ & $\begin{array}{l}5.016 \\
(4.336) * *\end{array}$ & 6.637 & 6.657 & \multirow[t]{2}{*}{2.318} & \multirow[t]{2}{*}{3.831} & \multirow[t]{2}{*}{6.149} \\
\hline Constant & $\begin{array}{l}-22.438 \\
(6.452)^{* *}\end{array}$ & $\begin{array}{l}-23.121 \\
(6.515)^{* *}\end{array}$ & & & $\begin{array}{l}-20.608 \\
(6.100)^{* *}\end{array}$ & \begin{tabular}{|l}
-29.539 \\
$(3.824)^{* *}$
\end{tabular} & & & & & \\
\hline F statistic & $14.75^{* *}$ & $14.21^{* *}$ & & & $60.59 * *$ & $43.33^{* *}$ & & & & & \\
\hline $\mathrm{R} 2$ & 0.334 & 0.342 & & & 0.525 & 0.540 & & & & & \\
\hline Sample size & 286 & 267 & & & 394 & 267 & & & & & \\
\hline
\end{tabular}

Notes:

1. Dependent variable is log of real gross crop income.

2. Omitted category is household receives no extension visits.

3. Absolute values of $\mathrm{t}$ statistics in parentheses. * significant at the $10 \%$ level; ** significant at the $5 \%$ level.

4. 'Sample 1' replicates the findings noted in Table 2. 'Sample 2' is restricted to households with gross crop income $>0$ in both survey rounds. 
Table 7: The role of initial conditions in determining log real gross crop income

\begin{tabular}{|c|c|c|}
\hline & $1982 / 83$ & 1995/96 \\
\hline Log agricultural tools & $\begin{array}{l}0.067 \\
(0.743)\end{array}$ & $\begin{array}{l}0.227 \\
(2.985)^{* *}\end{array}$ \\
\hline Log labor & $\begin{array}{l}-0.106 \\
(0.541)\end{array}$ & $\begin{array}{l}0.024 \\
(0.300)\end{array}$ \\
\hline Log land & $\begin{array}{l}0.772 \\
(5.582)^{* *}\end{array}$ & $\begin{array}{l}1.189 \\
(12.269)^{* *}\end{array}$ \\
\hline Number oxen pairs & $\begin{array}{l}0.245 \\
(3.178)^{* *}\end{array}$ & $\begin{array}{l}0.095 \\
(2.405)^{* *}\end{array}$ \\
\hline Receives at least one extension visit & $\begin{array}{l}-0.101 \\
(0.332)\end{array}$ & $\begin{array}{l}0.194 \\
(1.731)^{*}\end{array}$ \\
\hline Receives at least two extension visits & $\begin{array}{l}-0.104 \\
(0.360)\end{array}$ & $\begin{array}{c}0.014 \\
(0.120)\end{array}$ \\
\hline Receives at least three or more extension visits & $\begin{array}{l}0.028 \\
(0.124)\end{array}$ & $\begin{array}{l}-0.094 \\
(0.883)\end{array}$ \\
\hline Ln rainfall & $\begin{array}{l}2.613 \\
(3.371)^{* *}\end{array}$ & $\begin{array}{l}2.086 \\
(2.724)^{* *}\end{array}$ \\
\hline \multicolumn{3}{|l|}{ Initial conditions: Human capital } \\
\hline Years of education, household head & $\begin{array}{l}-0.034 \\
(1.450)\end{array}$ & $\begin{array}{l}0.023 \\
(1.719)^{*}\end{array}$ \\
\hline Head did 'skilled' work prior to being resettled & $\begin{array}{l}0.443 \\
(2.443)^{* *}\end{array}$ & $\begin{array}{l}0.061 \\
(0.418)\end{array}$ \\
\hline $\begin{array}{l}\text { Household received at least one extension visits } \\
\text { prior to being resettled }\end{array}$ & $\begin{array}{l}0.331 \\
(2.308)^{* *}\end{array}$ & $\begin{array}{l}-0.012 \\
(0.131)\end{array}$ \\
\hline \multicolumn{3}{|l|}{ Initial conditions: Location } \\
\hline Lived in protected village & $\begin{array}{l}0.429 \\
(2.177)^{* *}\end{array}$ & $\begin{array}{l}0.401 \\
(3.635)^{* *}\end{array}$ \\
\hline Lived in town & $\begin{array}{l}0.456 \\
(2.278)^{* *}\end{array}$ & $\begin{array}{l}0.014 \\
(0.096)\end{array}$ \\
\hline Lived in communal area & $\begin{array}{l}-0.147 \\
(0.917)\end{array}$ & $\begin{array}{l}-0.164 \\
(1.518)\end{array}$ \\
\hline \multicolumn{3}{|l|}{ Initial conditions: Social capital } \\
\hline Belonged to political organization & $\begin{array}{l}-0.045 \\
(0.275)\end{array}$ & $\begin{array}{l}-0.087 \\
(0.775)\end{array}$ \\
\hline Constant & $\begin{array}{l}-11.889 \\
(2.462)^{* *}\end{array}$ & $\begin{array}{l}-10.295 \\
(2.034)^{* *}\end{array}$ \\
\hline F statistic & $13.31 * *$ & $37.08 * *$ \\
\hline $\mathrm{R} 2$ & 0.386 & 0.572 \\
\hline
\end{tabular}

Notes:

1. Dependent variable is log of real gross crop income.

2. Specification, sample sizes and omitted group as per Table 2.

3. Absolute values of $\mathrm{t}$ statistics in parentheses. * significant at the $10 \%$ level; ** significant at the $5 \%$ level.

4. Sample sizes are $286(1982 / 83)$ and $353(1995 / 96)$. 
Table 8: Percentage changes in predicted real gross crop incomes

\begin{tabular}{|l|l|l|}
\hline $\begin{array}{l}\text { Deciles (ranked poorest to richest) based on } \\
\text { predicted log real gross incomes, 1982/83, } \\
\text { excluding impact of rainfall }\end{array}$ & $\begin{array}{l}\text { Mean percentage rate of growth } \\
\text { in predicted real gross crop } \\
\text { incomes, 1982/83 to 1995/96 }\end{array}$ & $\begin{array}{l}\text { Number of households reporting } \\
\text { decline in predicted gross crop } \\
\text { income }\end{array}$ \\
\hline Decile 1 & $328 \%$ & 0 \\
\hline Decile 2 & 272 & 0 \\
\hline Decile 3 & 293 & 0 \\
\hline Decile 4 & 272 & 0 \\
\hline Decile 5 & 268 & 0 \\
\hline Decile 6 & 261 & 0 \\
\hline Decile 7 & 220 & 0 \\
\hline Decile 8 & 217 & 0 \\
\hline Decile 9 & 206 & 0 \\
\hline Decile 10 & 160 & 1 \\
\hline
\end{tabular}

